Article

\title{
The Roles of the Structure and Basic Sites of Sodium Titanates on Transesterification Reactions to Obtain Biodiesel
}

\author{
Josue J. Machorro ${ }^{1}{ }^{\circledR}$, Ana L. Lazaro ${ }^{1}$, Fabricio Espejel-Ayala ${ }^{1}$, Eduardo Coutiño-Gonzalez ${ }^{2}$, \\ Juan C. Chavarria-Hernandez ${ }^{3}\left(\mathbb{D}\right.$, Luis. A. Godínez ${ }^{1}$ and Francisco J. Rodríguez-Valadez ${ }^{1, *}$ \\ 1 Centro de Investigación y Desarrollo Tecnológico en Electroquímica S. C., Parque Tecnológico Querétaro, \\ San Fandila Pedro Escobedo 76703, Mexico; jmachorro@cideteq.mx (J.J.M.); alazaro@cideteq.mx (A.L.L.); \\ fespejel@cideteq.mx (F.E.-A.); lgodinez@cideteq.mx (L.A.G.) \\ 2 Centro de Investigaciones en Óptica, A. C. Loma del Bosque 115, Colonia Lomas del Campestre, León, \\ Guanajuato 37150, Mexico; ecoutino@cio.mx \\ 3 Unidad de Energía Renovable, Centro de Investigación Científica de Yucatán A.C. Calle 43, Chuburna de \\ Hidalgo, Mérida 97205, Mexico; jc.ch@cicy.mx \\ * Correspondence: frodriguez@cideteq.mx
}

Received: 24 October 2019; Accepted: 19 November 2019; Published: 26 November 2019

\begin{abstract}
Sodium titanates were evaluated as heterogeneous catalysts for biodiesel production. Materials were prepared using an experimental design considering $\mathrm{NaOH}$ and $\mathrm{TiO}_{2}$ concentrations and hydrothermal and calcination temperatures as input variables. Materials characterization was carried out by DRX-Rietveld refinement, $\mathrm{CO}_{2}$-TPD, and XPS. Statistical analysis of the experimental results indicates that the calcination temperature is the most influential factor in the formation of sodium titanates with high catalytic performance in transesterification reactions. Further analysis of the oil-to-biodiesel conversion revealed that the catalytic activity of sodium titanates is directly correlated to the catalyst associated species and to the density of medium-strong basic sites on the surface of the material, obtaining up to $95 \%$ conversion to biodiesel at $60{ }^{\circ} \mathrm{C}$ using $3.6 \%$ weight catalyst with respect to oil.
\end{abstract}

Keywords: sodium titanates; heterogeneous catalysis; biodiesel

\section{Introduction}

Due to the growing worldwide demand for energy and the associated requirements to replace fossil fuels, increasing research efforts toward cleaner energy sources are being carried out all around the world. For instance, biodiesel production is an attractive option to replace diesel. The European Union, Indonesia, and Brazil are the main biodiesel producers, it is expected that by 2024, 34 trillion liters of biodiesel will be produced; $27 \%$ more than the production achieved in 2014 [1]. Biodiesel is obtained by transesterification reactions involving triglycerides from vegetable oils and/or animal fats and methanol with the aid of a catalyst. The process is typically carried out using homogeneous catalysis, which, although it is characterized by its low cost and high conversion efficiencies, has important drawbacks related to environmental issues associated with the large amounts of water that are required for neutralization and catalyst washing, and the need to use corrosion resistant equipment to produce the biofuel. In this context, the use of heterogeneous catalysts seems as a feasible solution to overcome these problems, since the material can be separated from the product mixture and its nature is less aggressive than the basic remnants of homogeneous catalysts. Among the heterogeneous catalysts that have been explored in biodiesel production, we found waste materials [2], zeolites [3], and metal oxides, such as $\mathrm{CaO}, \mathrm{TiO}_{2}, \mathrm{MgO}$, and $\mathrm{ZnO}$ [4-6]. Sodium titanates are promising materials that have 
been studied for biodiesel production. In this context, $97 \%$ conversion efficiency for biodiesel has been obtained via transesterification of triglycerides and up to $54 \%$ via photocatalytic esterification of fatty acids $[7,8]$. Potassium-based titanates are also very attractive since close to $100 \%$ biodiesel production conversions have been reported $[9,10]$. Other types of titanate materials have shown great potential for biodiesel production. Potassium-doped sodium titanate nanotubes for instance, are characterized by larger basicity which contributes to biodiesel conversion [11,12]. Mesoporous calcium titanates have also shown conversions above $80 \%$ via transesterification of reused cooking oils [13]. Titanates' catalytic performances depend on the surface structure of the substrate, and this in turn, is a function of the substrate's synthetic approach. In this way, highly active titanate-based catalysts of potassium and rare earths are obtained by hydrothermal synthesis at $120^{\circ} \mathrm{C}[14,15]$, and up to $200^{\circ} \mathrm{C}[16]$, respectively. Other synthetic approaches, such as sol-gel, can also be used to obtain highly active catalysts for biodiesel production [17]. Since Kasuga and colleagues obtained this type of materials [18], several groups have reported variations of the methodology to produce different species, such as protonated titanates $\left(\mathrm{H}_{2} \mathrm{Ti}_{3} \mathrm{O}_{7}\right)$, sodium trititanate $\left(\mathrm{Na}_{2} \mathrm{Ti}_{3} \mathrm{O}_{7}\right)$, sodium hexatitanate $\left(\mathrm{Na}_{2} \mathrm{Ti}_{6} \mathrm{O}_{13}\right)$, and sodium nonatitanate $\left(\mathrm{Na}_{2} \mathrm{Ti}_{9} \mathrm{O}_{19}\right)$ [19-21]. One of the main features that makes sodium titanates attractive, is the particular interaction of the cations with oxygen $\left(\mathrm{M}^{+}-\mathrm{O}^{-}-\mathrm{Ti}^{+}\right)$, providing basic sites for the transesterification reaction [15,22]. Although these materials have been successfully used for biodiesel obtention, there is little information on the correlation between crystalline phases of sodium titanates and its catalytic performance in transesterification reactions. In this study the effect of sodium titanates synthesis conditions on its catalytic performance in transesterification reactions was evaluated by means of an experimental design $2^{4}$ (using $\mathrm{NaOH}$ and $\mathrm{TiO}_{2}$ concentration, and hydrothermal and calcination temperatures, as input variables). Calcination temperature proved itself to have an important role in the obtention of sodium titanates with high catalytic performance for biodiesel production; further analysis of the oil-to-biodiesel conversion revealed that the catalytic activities of sodium titanates are directly correlated to the catalyst-associated species and to the density of strong-medium basic sites on the surface of the material. Up to 95\% conversion to biodiesel was obtained.

\section{Results and Discussion}

\subsection{Characterization and Catalytic Performance of Sodium Titanates}

The biodiesel conversions obtained using the 20 catalysts under study are shown in Table 1 . The highest biodiesel conversion was $35.5 \%$ for the $\mathrm{C} 18$ catalyst; a value that is larger than that reported by Hernández-Hipólito and co-workers under analogous reaction conditions [7].

Statistical analysis of the experimental design (using Statgraphics Centurion XV®version 15.1.02 from Statgraphics Technologies, inc., Virginia, VA, USA) showed that, under a 95\% significance level, the calcination temperature is the most influential factor in the formation of sodium titanates characterized by high catalytic performance for biodiesel production (Figure 1). In previous reports, the calcination temperature had been identified as the controlling factor in sodium titanates' compositions. Morgado et al. [23] and Qamar et al. [24] separately reported the production of hydrated sodium trititanates with formula $\mathrm{Na}_{x} \mathrm{H}_{2-\mathrm{x}} \mathrm{Ti}_{3} \mathrm{O}_{7}{ }^{*} \mathrm{nH}_{2} \mathrm{O}$ or $\mathrm{Na}_{2} \mathrm{Ti}_{3} \mathrm{O}_{7}{ }^{*} \mathrm{nH}_{2} \mathrm{O}$ that were transformed into dehydrated sodium trititanate $\left(\mathrm{Na}_{2} \mathrm{Ti}_{3} \mathrm{O}_{7}\right)$ and/or sodium hexatitanates $\left(\mathrm{Na}_{2} \mathrm{Ti}_{6} \mathrm{O}_{13}\right)$, depending on the calcination temperature. On the other hand, Xiaoming and co-workers pointed out the effect of calcination temperature on sodium titanates, reporting the formation of sodium nonatitanate $\left(\mathrm{Na}_{2} \mathrm{Ti}_{9} \mathrm{O}_{19}\right)$ at $600{ }^{\circ} \mathrm{C}$ and sodium hexatitanate at $850{ }^{\circ} \mathrm{C}$ [25].

To gain deeper understanding of the relationship between the catalytic activity and the sodium titanate species present in the materials, we selected three samples, one with the best conversion (C18), one with the lowest conversion (C11), and one with an intermediate behavior (C1); these materials were calcined at different temperatures $\left(600,800\right.$, and $400{ }^{\circ} \mathrm{C}$, respectively), and characterized by DRX-Rietveld, $\mathrm{CO}_{2}$-TPD, and XPS, to determine crystalline phases, basic active sites, and surface electronic states present in each catalyst. For comparative purposes a $\mathrm{TiO}_{2} \mathrm{P}_{2} 5$ Aeroxide sample was included in the analysis (Table 1). 
Table 1. Catalysts' synthesis conditions and related biodiesel conversions.

\begin{tabular}{|c|c|c|c|c|c|c|}
\hline & Catalyst. & $\begin{array}{c}\mathrm{NaOH} \\
\begin{array}{c}\text { Concentration } \\
(\mathrm{mol} / \mathrm{L})\end{array}\end{array}$ & $\begin{array}{c}\text { Hydrothermal } \\
\text { Temperature } \\
\left({ }^{\circ} \mathrm{C}\right)\end{array}$ & $\begin{array}{c}\text { Amount of } \\
\mathrm{TiO}_{2}(\mathrm{~g} / \mathrm{mL})\end{array}$ & $\begin{array}{c}\text { Calcination } \\
\text { Temperature } \\
\left({ }^{\circ} \mathrm{C}\right)\end{array}$ & $\begin{array}{c}\text { Biodiesel } \\
\text { Conversion } \\
\text { (Mass/Mass \%) }\end{array}$ \\
\hline & $\mathrm{TiO}_{2}$ & - & - & - & - & 4 \\
\hline & $\mathrm{C} 1$ & 7.5 & 170 & 0.12 & 400 & 10 \\
\hline & $\mathrm{C} 2$ & 7.5 & 170 & 0.06 & 400 & 9.5 \\
\hline & $\mathrm{C} 3$ & 7.5 & 170 & 0.06 & 800 & 1.8 \\
\hline & $\mathrm{C} 4$ & 7.5 & 130 & 0.06 & 800 & 1.7 \\
\hline & C5 & 2.5 & 130 & 0.12 & 400 & 5.7 \\
\hline & C6 & 7.5 & 170 & 0.12 & 800 & 6.5 \\
\hline & C7 & 7.5 & 130 & 0.12 & 400 & 11 \\
\hline & $\mathrm{C} 8$ & 2.5 & 170 & 0.06 & 400 & 11.6 \\
\hline & C9 & 7.5 & 130 & 0.12 & 800 & 4.8 \\
\hline & C10 & 7.5 & 130 & 0.06 & 400 & 10 \\
\hline & C11 & 2.5 & 170 & 0.06 & 800 & 0.2 \\
\hline & C12 & 2.5 & 130 & 0.06 & 400 & 5.7 \\
\hline & C13 & 2.5 & 130 & 0.12 & 800 & 0.3 \\
\hline & C14 & 2.5 & 170 & 0.12 & 800 & 0.3 \\
\hline & C15 & 2.5 & 170 & 0.12 & 400 & 9.8 \\
\hline & C16 & 2.5 & 130 & 0.06 & 800 & 0.3 \\
\hline \multirow{4}{*}{$\begin{array}{l}\text { Central } \\
\text { points }\end{array}$} & C17 & 5 & 150 & 0.09 & 600 & 30.3 \\
\hline & C18 & 5 & 150 & 0.09 & 600 & 35.5 \\
\hline & C19 & 5 & 150 & 0.09 & 600 & 35 \\
\hline & C20 & 5 & 150 & 0.09 & 600 & 28.6 \\
\hline
\end{tabular}

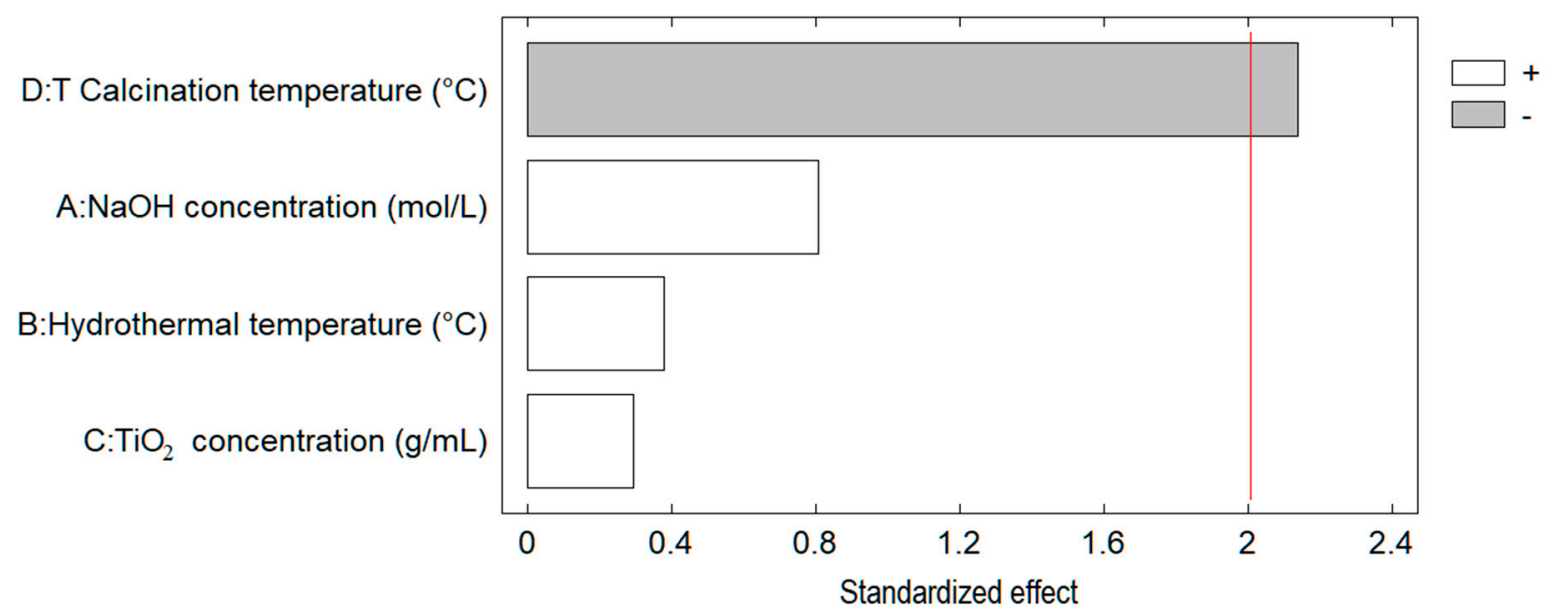

Figure 1. Standardized Pareto chart of the catalysts' synthesis conditions for biodiesel conversion.

Correlations between sodium titanates' structural phases and catalytic activities were first assessed from the X-ray diffractograms, depicted in Figure 2a. Inspection of this figure shows that for the three catalysts, diffraction peaks associated to $\mathrm{Na}_{2} \mathrm{Ti}_{6} \mathrm{O}_{13}$ (JCPDS number 01-080-5525) and $\mathrm{Na}_{2} \mathrm{Ti}_{3} \mathrm{O}_{7}$ (JCPDS number 01-070-9440) were observed, whereas for $\mathrm{C} 18$, catalyst additional diffraction patterns that could be indexed to $\mathrm{Na}_{2} \mathrm{Ti}_{9} \mathrm{O}_{19}$ (JCPDS number 01-078-1590) were identified. By using Rietveld refining analysis, it was also possible to obtain the ratio of chemical species present in the catalysts (Figure 2b). This figure shows that, while the best performing material (C18) contained $44.9 \% \mathrm{Na}_{2} \mathrm{Ti}_{3} \mathrm{O}_{7}, 31.3 \%$ $\mathrm{Na}_{2} \mathrm{Ti}_{9} \mathrm{O}_{19}$, and $22.4 \% \mathrm{Na}_{2} \mathrm{Ti}_{6} \mathrm{O}_{13}, \mathrm{C} 1$ catalyst (with a conversion of $10 \%$ ) contained $86.8 \% \mathrm{Na}_{2} \mathrm{Ti}_{6} \mathrm{O}_{13}$ and $13.2 \% \mathrm{Na}_{2} \mathrm{Ti}_{3} \mathrm{O}_{7}$; and $\mathrm{C} 11$ catalyst was composed mostly of $\mathrm{TiO}_{2}$ rutile and a small fraction of $\mathrm{Na}_{2} \mathrm{Ti}_{6} \mathrm{O}_{13}$. 


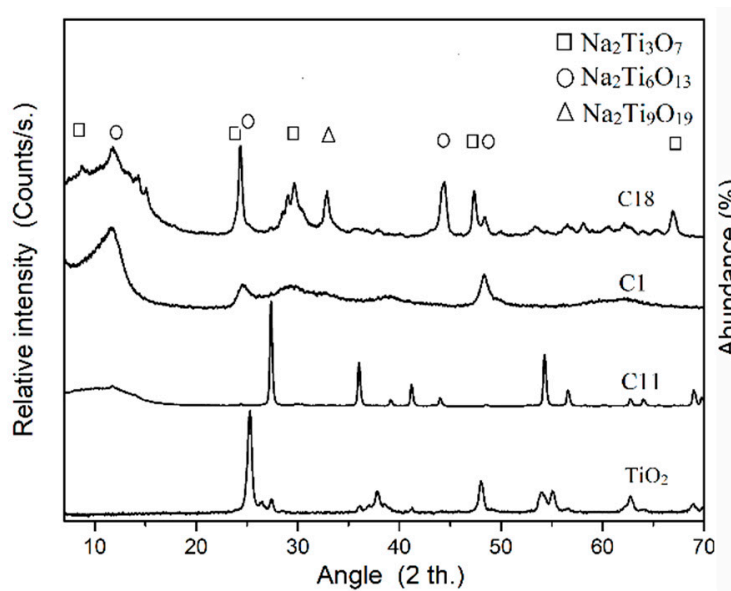

a)

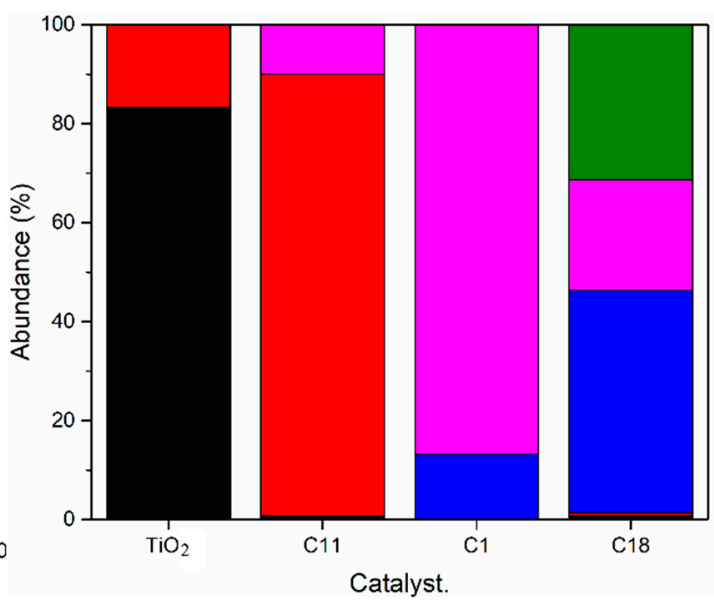

b)

Figure 2. (a) X-ray diffraction patterns, and (b) proportion of chemical structures in $\mathrm{TiO}_{2}, \mathrm{C} 1, \mathrm{C} 11$, and $\mathrm{C} 18$ catalysts. Anatase (black bar), rutile (red bar), $\mathrm{Na}_{2} \mathrm{Ti}_{3} \mathrm{O}_{7}$ (blue bar), $\mathrm{Na}_{2} \mathrm{Ti}_{6} \mathrm{O}_{13}$ (pink bar), and $\mathrm{Na}_{2} \mathrm{Ti}_{9} \mathrm{O}_{19}$ (green bar).

To correlate the structural information with the basicity of the materials surface, $\mathrm{CO}_{2}$-TPD experiments were carried out to assess the basic sites density on the catalysts surface. The results show two types of basic surface sites: weak basic sites $\left(<400{ }^{\circ} \mathrm{C}\right)$ and medium-strong basic sites $\left(>400^{\circ} \mathrm{C}\right)$. As can be seen in Figure 3a, the desorption curves for all the catalysts revealed that the most notorious signals corresponding to weak basic sites appeared at $130^{\circ} \mathrm{C}$ for $\mathrm{C} 1$ catalyst, which were followed by $\mathrm{C} 18$ at $88^{\circ} \mathrm{C}$ and $\mathrm{C} 11$ at $75^{\circ} \mathrm{C}$. In addition, a desorption signal at $515^{\circ} \mathrm{C}$ was only observed for $\mathrm{C} 18$ catalyst; this could correspond to medium-strong basic sites according to Aramendia and collaborators [26]. Figure $3 \mathrm{~b}$ summarizes the information related to the total basic sites values obtained. The data is presented in terms of micromoles of desorbed $\mathrm{CO}_{2}$ per gram of catalyst. Inspection of Figure $3 \mathrm{~b}$ shows that, while the catalyst with the worst performance, $\mathrm{C} 11$ is also the one with the lowest density of total basic sites; the intermediate performing catalyst, $\mathrm{C} 1$, is the material with the highest density of basic sites (although mainly weak basic sites). It is also interesting to note that these two materials, C1 and C11, with the largest and lowest number of basic sites, show predominantly weak-type basic sites. The best performing (C18) catalyst on the other hand, is characterized by an intermediate density of basic sites, $192.6(\mu \mathrm{mol} / \mathrm{g})$, but this material is the only one that displayed medium-strong type basic-sites.

Medium-strong basic sites detected could be correlated to the $\mathrm{Na}_{2} \mathrm{Ti}_{3} \mathrm{O}_{7}$ species identified principally in the $\mathrm{C} 18$ catalyst. In structural terms, the difference between $\mathrm{Na}_{2} \mathrm{Ti}_{3} \mathrm{O}_{7}$ and $\mathrm{Na}_{2} \mathrm{Ti}_{6} \mathrm{O}_{13}$ or $\mathrm{Na}_{2} \mathrm{Ti}_{9} \mathrm{O}_{19}$, is that the former presents a lamellar structure with $\mathrm{Ti}_{3} \mathrm{O}_{7}^{2-}$ corrugated layers and two interlamellar $\mathrm{Na}^{+}$ions $[27,28]$; in addition, $\mathrm{Na}_{2} \mathrm{Ti}_{6} \mathrm{O}_{13}$ and $\mathrm{Na}_{2} \mathrm{Ti}_{9} \mathrm{O}_{19}$ shows a tunnel-like structure with two $\mathrm{Na}^{+}$ions inside the structure [24,29-31]. Wang and collaborators [32,33] determined by first principles, DFT calculations among the structures of $\mathrm{Na}_{2} \mathrm{Ti}_{6} \mathrm{O}_{13}, \mathrm{Na}_{2} \mathrm{Ti}_{3} \mathrm{O}_{7}$, and $\mathrm{TiO}_{2}$ (anatase); $\mathrm{Na}_{2} \mathrm{Ti}_{3} \mathrm{O}_{7}$ displayed a higher chemical reactivity, and such reactivity was explained by the coordination number of oxygen atoms present in the lattice of each crystalline phase and by their surrounding chemical environment. According to this study, the least reactive structures are $\mathrm{TiO}_{2}$ (anatase) and $\mathrm{Na}_{2} \mathrm{Ti}_{6} \mathrm{O}_{13}$, having oxygen coordination numbers of three and two respectively, compared to coordination of one for $\mathrm{Na}_{2} \mathrm{Ti}_{3} \mathrm{O}_{7}$. 


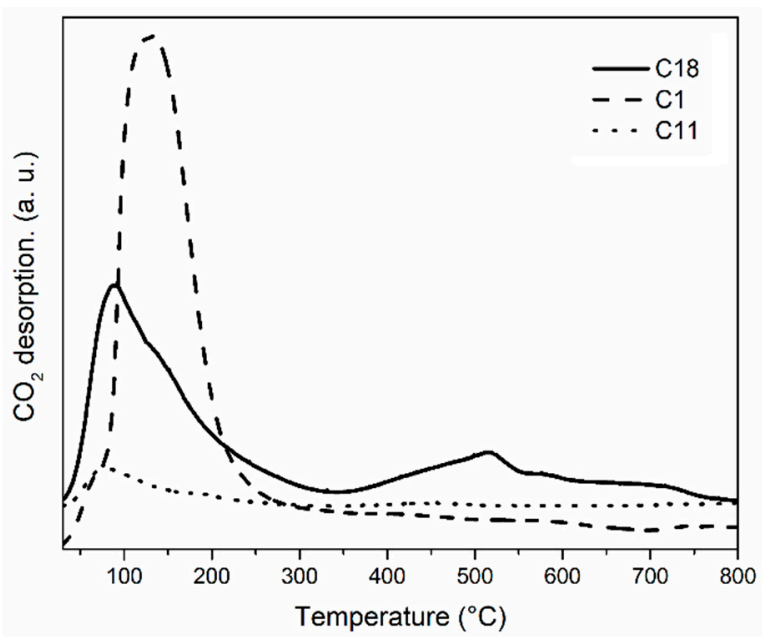

a)

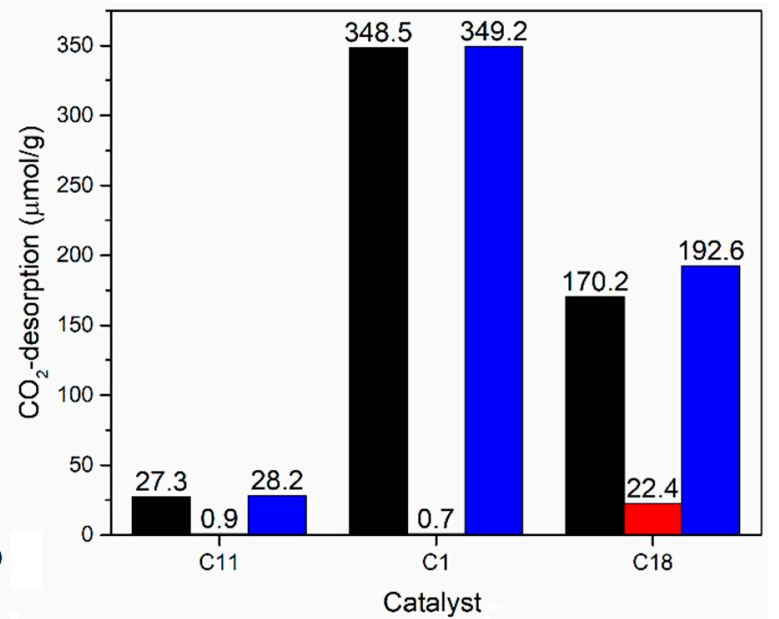

b)

Figure 3. (a) TPD profiles and (b) basic sites-related $\mathrm{CO}_{2}$ desorption values for $\mathrm{C} 1, \mathrm{C} 11$, and $\mathrm{C} 18$ catalysts. Weak basic sites (black bar), medium-strong basic sites (red bar), and total basic sites (blue bar).

Using XPS (Figure 4), it was possible to identify two oxidation states for titanium $(3+, 4+)$. While for $\mathrm{C} 11$, a peak at $458.4 \mathrm{eV}$ reveals, mainly, the presence of $\mathrm{Ti}^{4+}\left(\mathrm{TiO}_{2}\right.$, rutile phase) [34], $\mathrm{C} 1$ and $\mathrm{C} 18$ are characterized by a distribution of $\mathrm{Ti}^{4+}$ and $\mathrm{Ti}^{3+}$ species. It is interesting to note that $\mathrm{C} 18$ (best performing catalyst) displays a higher $\mathrm{Ti}^{3+}$ presence compared to $\mathrm{C} 1$ (Table 2). This oxidation state of titanium can occur due to a defect in the structure; specifically, an oxygen vacancy [35,36]. Likewise, it could be attributed to the insertion of sodium ions into the structure of $\mathrm{TiO}_{2}[37,38]$. This is in agreement with our XRD observations, where $\mathrm{Na}_{2} \mathrm{Ti}_{3} \mathrm{O}_{7}$ is the predominant species in catalyst $\mathrm{C} 18$, and this crystalline phase among the other crystalline phases, has more sodium in its structure [39]. These findings suggest a possible correlation between the performance of $\mathrm{C} 18$ catalyst with the larger presence of $\mathrm{Na}_{2} \mathrm{Ti}_{3} \mathrm{O}_{7}$ as active crystalline phase, and the medium-strong basic sites present in this material.

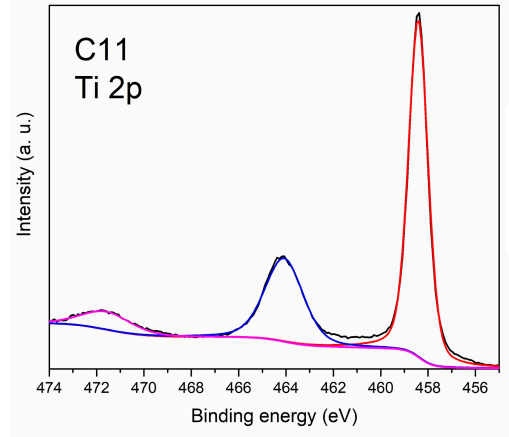

a)

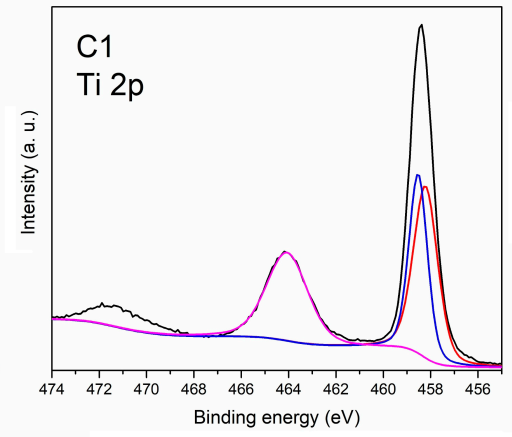

b)

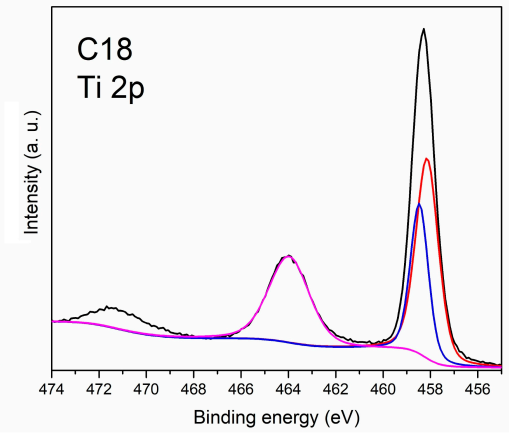

c)

Figure 4. Ti 2p XPS spectra obtained for (a) C11, (b) C1, and (c) C18, catalysts.

In addition to the surface chemistry effects on catalytic activity, synthesis procedures determine the physical properties of the materials, and therefore, their catalytic capacity. For example, it has been shown that calcination temperature affects the surface crystal structure, the area, and the pore morphologies, and that a balance of these factors should be reflected in the catalytic activity of the material. In this regard, there is evidence of a decrease in surface area and porosity as the calcination temperature for sodium titanates increases [23,40]. Considering from the surface chemistry perspective, that there is an increasing catalytic activity as the calcination temperature increases, a balance of physical and chemical calcination temperature effects should result in an optimum performance of the 
catalyst at an intermediate calcination temperature. In agreement with this reasoning, $\mathrm{C} 18$, which is the catalyst prepared at an intermediate temperature, is the best performing material of those surveyed.

Table 2. Binding energies (BE) of the Ti 2p electrons, and the percentage area of each deconvoluted peak.

\begin{tabular}{|c|c|c|c|c|}
\hline \multirow{2}{*}{ Catalyst. } & \multicolumn{2}{|c|}{ Ti (III) } & \multicolumn{2}{|c|}{ Ti (IV) } \\
\hline & BE $(e V)$ & Area (\%) & BE (eV) & Area (\%) \\
\hline \multirow{2}{*}{$\mathrm{C} 1$} & \multirow{2}{*}{458.2} & \multirow{2}{*}{37.5} & 458.5 & 30.0 \\
\hline & & & 464.1 & 32.5 \\
\hline \multirow{2}{*}{ C18 } & \multirow{2}{*}{458.1} & \multirow{2}{*}{42.2} & 458.4 & 25.3 \\
\hline & & & 463.9 & 32.5 \\
\hline \multirow{2}{*}{ C11 } & \multirow{2}{*}{ - } & \multirow{2}{*}{ - } & 458.4 & 67.4 \\
\hline & & & 464.1 & 32.6 \\
\hline
\end{tabular}

References [34,41] were used for titanium binding energies assignments.

\subsection{Biodiesel Conversion Optimization}

To optimize the biodiesel production, the catalyst with the best performance (C18) was used in a $2^{3}$ directed design with four central points, using as input variables the amount of catalyst, methanol:oil molar ratio, and reaction time. The best reaction conditions to obtain up to $95 \%$ of biodiesel are shown in Table 3. The amount of catalyst was the most significant variable in this study (Figure 5). These results are comparable to those reported in previous works where exclusively sodium titanates were used as heterogeneous catalysts in biodiesel production [7].

Table 3. Experimental design of the reaction parameters for biodiesel conversion optimization.

\begin{tabular}{cccccc}
\hline Run. & $\begin{array}{c}\text { Cat. Weight } \\
\text { (Cat/Oil \%) }\end{array}$ & $\begin{array}{c}\text { M. R. } \\
\text { (MeOH:Oil) }\end{array}$ & Time (h) & $\begin{array}{c}\text { Biodiesel Conversion } \\
\text { (Mass/Mass \%) }\end{array}$ \\
\hline 1 & 5.5 & 60 & 2 & 70 \\
2 & 5.5 & 60 & 8 & 91 \\
3 & 5.5 & 20 & 2 & 86 \\
& 4 & 5.5 & 20 & 8 & 88 \\
& 5 & 1.8 & 60 & 2 & 33 \\
6 & 1.8 & 60 & 8 & 74 \\
Central points & 1.8 & 20 & 2 & 28 \\
& 7 & 1.8 & 20 & 8 & 63 \\
\hline & 10 & 3.6 & 40 & 5 & 90 \\
& 11 & 3.6 & 40 & 5 & 95 \\
& 12 & 3.6 & 40 & 5 & 93 \\
\hline
\end{tabular}

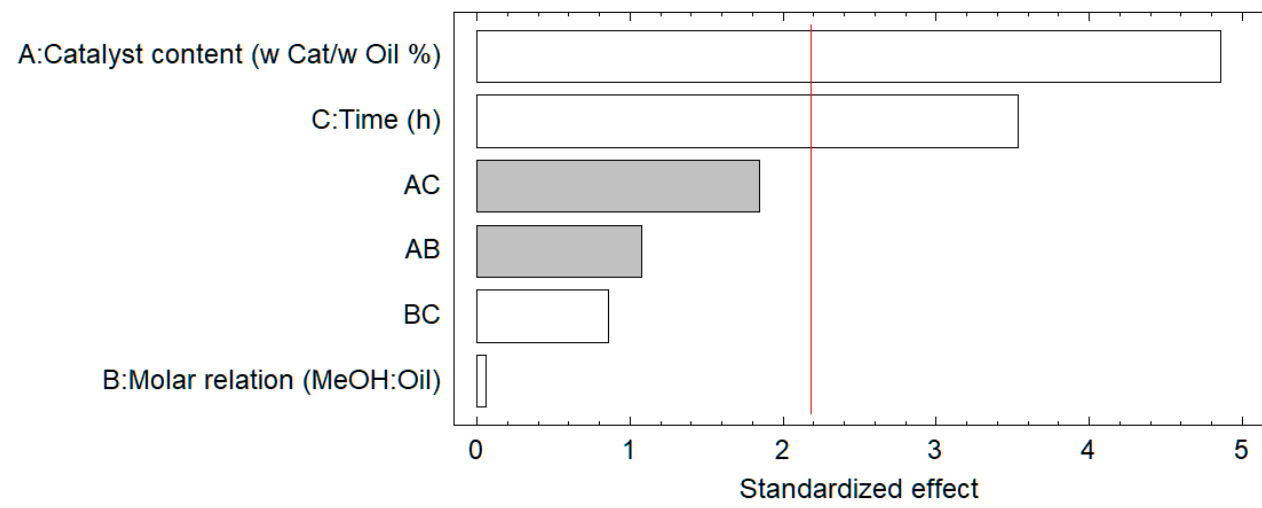

Figure 5. Standardized Pareto chart of the reaction parameters for biodiesel conversion optimization. 


\section{Materials and Methods}

\subsection{Materials}

Titanium dioxide Aeroxide P25 (Evonik industries, Isehara-shi, OL, Japan) and reagent grade sodium hydroxide (Macron fine chemicals, Switzerland) were used to obtain the sodium titanate. For the synthesis of biodiesel, anhydrous methanol-reactive grade (J.T. Baker, Trinidad and Tobago), and commercial soybean oil (Imperial ${ }^{\circledR}$, The Calvario, Tehuacan, Puebla, Pue, Mexico) were used. For gas chromatography analysis, HPLC-grade pyridine (Avantor Performance Materials, Inc., Center Valley, PA, USA), n-heptane (Sigma Aldrich, Steinheim, Germany), methyl heptadecanoate (Sigma Aldrich, St. Louis, MO, USA), and fatty acid methyl ester standards (Sigma Aldrich, Bellefonte, PA, USA) were used. N-Trimethylsilyl-N-methyl trifluoroacetamide (MSTFA) on the other hand, was obtained from Agilent (Agilent technologies, Santa Clara, CA, USA) and used as received.

\subsection{Preparation of Catalytic Materials}

To study the effect of the synthesis conditions of sodium titanate catalysts, a $2^{4}$ randomized experimental design with four central points was applied, in accordance with the literature [42]. The corresponding factors and levels $(-1,0,1)$ for the synthesis of each of the twenty synthesized catalysts are shown in Table 4. All catalytic materials were prepared by hydrothermal method, where the indicated amount of $\mathrm{TiO}_{2}$ was weighed and placed in agitation in a sodium hydroxide solution for $17 \mathrm{~h}$ in an airtight Teflon container at $90{ }^{\circ} \mathrm{C}$. Subsequently, the liquid was transferred to an autoclave and placed in an oven for $24 \mathrm{~h}$ at the corresponding hydrothermal synthesis temperature. The material was then washed with deionized water until a $\mathrm{pH} \sim 7$ was obtained in the supernatant; the recovered solid was dried for $4 \mathrm{~h}$ at $120^{\circ} \mathrm{C}$; then, grinded with a mortar and sieved with a 0.004 inch mesh. Finally, the material was calcined for $3 \mathrm{~h}$ at the corresponding temperature.

Table 4. Experimental design for the synthesis of sodium titanate catalysts.

\begin{tabular}{|c|c|c|c|c|c|c|c|c|c|c|c|c|}
\hline \multirow{4}{*}{$\begin{array}{c}\text { Coded } \\
\text { level }\end{array}$} & \multicolumn{12}{|c|}{ Values Used in the Experimental Design } \\
\hline & \multicolumn{3}{|c|}{$\begin{array}{c}\mathrm{NaOH} \\
\text { Concentration }(\mathrm{mol} / \mathrm{L})\end{array}$} & \multicolumn{3}{|c|}{$\begin{array}{l}\text { Hydrothermal Synthesis } \\
\text { Temperature }\left({ }^{\circ} \mathrm{C}\right)\end{array}$} & \multicolumn{3}{|c|}{$\begin{array}{c}\text { Amount of } \mathrm{TiO}_{2} \\
(\mathrm{~g} / \mathrm{mL})\end{array}$} & \multicolumn{3}{|c|}{$\begin{array}{c}\text { Calcination } \\
\text { Temperature }\left({ }^{\circ} \mathrm{C}\right)\end{array}$} \\
\hline & -1 & 0 & 1 & -1 & 0 & 1 & -1 & 0 & 1 & -1 & 0 & 1 \\
\hline & 2.5 & 5 & 7.5 & 130 & 150 & 170 & 0.06 & 0.09 & 0.12 & 400 & 600 & 800 \\
\hline
\end{tabular}

\subsection{Characterization of the Catalytic Materials}

X-ray Diffraction tests were performed on a D-500 apparatus (Siemens Corporation, Cherry Hill, NJ, USA), equipped with a $\mathrm{CuK} \alpha$ radiation source working at a scan rate of $0.5^{\circ}(2 \theta / \mathrm{min})$. Identification of sodium titanate phases was carried out by the Rietveld analysis technique using the Topas ${ }^{\circledR} 6.2$ software supplied by Bruker (Bruker Corporation, Karlsruhe, Germany). The resulting data can be looked at in the Supplementary Material Link. Basicity was assessed by temperature programmed $\mathrm{CO}_{2}$ desorption experiments using a BelCat apparatus (MicrotracBEL Corp., Osaka, Japan). Initially, 50 milligrams of the samples were treated with helium flow $(30 \mathrm{~mL} / \mathrm{min})$ at $400{ }^{\circ} \mathrm{C}$ for $2 \mathrm{~h}$. Afterwards, the samples were cooled to room temperature and set under a $5 \% \mathrm{CO}_{2} / \mathrm{He}$ flow $(30 \mathrm{~mL} / \mathrm{min}) \mathrm{for}$ $30 \mathrm{~min}$, followed by a purge of the remaining $\mathrm{CO}_{2}$ with helium gas. Finally, desorption experiments were conducted from $30^{\circ} \mathrm{C}$ to $800{ }^{\circ} \mathrm{C}$ with a ramp of $10{ }^{\circ} \mathrm{C} / \mathrm{min}$ under a constant helium flow of $30 \mathrm{~mL} / \mathrm{min}$. $\mathrm{CO}_{2}$ desorption was measured with a thermal conductivity and a mass detector (TCD-Ms). The quantification was done based on the integration of the area under the curve using the Origin ${ }^{\circledR}$ 2015 software. X-ray photoemission spectroscopy (XPS) was performed using a K-ALFA ${ }^{\mathrm{TM}}$ equipment, (Thermo Fisher Scientific, Newington, NH, USA). 


\subsection{Synthesis and Quantification of Biodiesel}

The transesterification reaction was carried out in triplicate assays in a three-necked flask (attached to a refrigerant) at $60{ }^{\circ} \mathrm{C}$, with a molar methanol:oil ratio of $20: 1$ and $1.85 \%$ (500 mg) weight of catalyst with respect to the weight of the oil. The mixture was kept under vigorous stirring for $2 \mathrm{~h}$. The conditions reported by Hernández-Hipólito and collaborators [7] were selected for comparative purposes and to perform an initial screening of the catalytic performance of the 20 obtained materials. In a second stage, the best performing materials were further explored to optimize the biodiesel conversion varying the reaction conditions by means of a $2^{3}$ design (two levels and central points $[-1,0,1])$ shown in Table 5. Quantification of biodiesel conversion was performed in an Agilent 7890A gas-chromatograph, coupled to an ionized flame detector (FID) and a mass detector ((MS) model 5975C) using a $15 \mathrm{~m}$ BD-ASTMD6584 column, with an internal diameter of $0.32 \mathrm{~mm}$ and a film coating of $0.1 \mu \mathrm{m}$. The gas chromatographic method that was employed is based on the ASTM D6584-17 procedure [43]. Sample preparation was conducted following the ASTM D6584-17 and EN14103 methodologies [44], placing $100 \mathrm{mg}$ of biodiesel in a vial (upper phase, filtered with $0.45 \mu \mathrm{m}$ acrodisk and without methanol), along with $1 \mathrm{~mL}$ of internal standard (methyl heptadecanoate in pyridine, $9.7 \mathrm{mg} / \mathrm{mL}$ ) and $100 \mu \mathrm{L}$ of MSTFA. This mixture was shaken and let rest for $15 \mathrm{~min}$; that was followed by the addition of $7 \mathrm{~mL}$ of n-heptane. After homogenization by proper stirring, a $1.5 \mathrm{~mL}$ aliquot was taken and transferred to a vial for analysis; the equation to calculate biodiesel conversion by chromatography, is shown in the Supplementary Material Section.

Table 5. Experimental design to study the effect of reaction conditions for biodiesel conversion optimization.

\begin{tabular}{|c|c|c|c|c|c|c|c|c|c|}
\hline \multirow[b]{3}{*}{ Coded level } & \multicolumn{9}{|c|}{ Range of Factors Used } \\
\hline & \multicolumn{3}{|c|}{$\begin{array}{l}\text { Catalyst Weight } \\
\text { (Cat/Oil \%) }\end{array}$} & \multicolumn{3}{|c|}{$\begin{array}{l}\text { Molar Relation } \\
\text { (MeOH:Oil) }\end{array}$} & \multicolumn{3}{|c|}{$\begin{array}{l}\text { Reaction Time } \\
\text { (h) }\end{array}$} \\
\hline & -1 & 0 & 1 & -1 & 0 & 1 & -1 & 0 & 1 \\
\hline & 1.8 & 3.6 & 5.5 & $20: 1$ & $40: 1$ & $60: 1$ & 2 & 5 & 8 \\
\hline
\end{tabular}

\section{Conclusions}

In this report, a correlation between sodium titanates' associated species and the density of basic sites on the materials surface for the production of biodiesel via transesterification reactions, was conducted. It was observed that calcination temperature played a key role in the synthesis of sodium titanates, with high catalytic activity in transesterification reactions. Three different catalysts (C1, C11, and C18) were selected to further study the effects of crystalline phases associated and basic sites, on the materials' catalytic activities. Whereas for the worst (C11) and intermediate (C1) performing catalysts, $\mathrm{TiO}_{2}$ (rutile phase) and $\mathrm{Na}_{2} \mathrm{Ti}_{6} \mathrm{O}_{13}$ structures were predominantly observed, $\mathrm{C} 18$ (the best performing material) was characterized by a dominant proportion of $\mathrm{Na}_{2} \mathrm{Ti}_{3} \mathrm{O}_{7}$ species. Analysis of these materials by TPD of $\mathrm{CO}_{2}$ was conducted to assess the basicity of the catalysts' surface structures. Interestingly, it was found that the catalytic performances of the different materials not only depends on the surface densities of the basic active sites, but also on their corresponding basic strengths. Through XPS it was possible to observe a larger presence of $\mathrm{Ti}^{3+}$ species in $\mathrm{C} 18$ catalyst, which could be associated to $\mathrm{Na}_{2} \mathrm{Ti}_{3} \mathrm{O}_{7}$. An optimization of the transesterification reaction conditions using a directed design $2^{3}$ (four central points) employing the best performing material (C18) resulted in conversions of up to $95 \%$ at $60{ }^{\circ} \mathrm{C}$ using a $3.6 \%$ wt catalyst with respect to oil. In the present report, a combinatorial approach was followed to correlate the structures and basic sites of sodium titanates to their catalytic activities in transesterification reactions. Such an approach could be potentially extended to other chemical reactions where sodium titanates are employed as catalysts. 
Supplementary Materials: The following are available online at http://www.mdpi.com/2073-4344/9/12/989/s1. Rietveld methodology, equation for biodiesel conversion using chromatography.

Author Contributions: Conceptualization, J.J.M., F.J.R.-V., J.C.C.-H., and F.E.-A.; resources, J.J.M., and J.C.C.-H.; formal analysis, J.J.M., A.L.L., and E.C.-G.; writing-original draft preparation, J.J.M., A.L.L., and L.A.G.; writing—review and editing, J.J.M., E.C.-G., F.J.R.-V., and L.A.G.

Funding: This research was funded by the National Science and Technology Council of Mexico (CONACYT) trough Grant FSE 250014 (Cluster Biodiesel Avanzado). APC were paid by the Electrochemical Research and Technological Development Center (CIDETEQ).

Acknowledgments: The authors thank Raúl Pérez Hernández for $\mathrm{CO}_{2}$-TPD analysis carried out at Instituto Nacional de Investigaciones Nucleares (ININ, Mexico); Araceli Jacobo Azuara for DRX tests conducted at the University of Guanajuato (Mexico) and CONACYT for a graduate fellowship to J.J. Machorro. E.C.-G. also acknowledges CONACYT for the support provided by the Cátedras-CONACYT young researcher program.

Conflicts of Interest: The authors declare no conflict of interest.

\section{References}

1. Organisation for Economic Co-operation and Development, Food and Agriculture Organization of the United Nations. Biofuels. In OECD-FAO Agric. Outlook 2015-2024; OECD Publishing: Paris, France, 2015; pp. 126-142. [CrossRef]

2. Marwaha, A.; Rosha, P.; Mohapatra, S.K.; Mahla, S.K.; Dhir, A. Waste materials as potential catalysts for biodiesel production: Current state and future scope. Fuel Process. Technol. 2018, 181, 175-186. [CrossRef]

3. Du, L.; Ding, S.; Li, Z.; Lv, E.; Lu, J.; Ding, J. Transesterification of castor oil to biodiesel using NaY zeolite-supported La2O3 catalysts. Energy Convers. Manag. 2018, 173, 728-734. [CrossRef]

4. Kouzu, M.; Fujimori, A.; Suzuki, T.; Koshi, K.; Moriyasu, H. Industrial feasibility of powdery CaO catalyst for production of biodiesel. Fuel Process. Technol. 2017, 165, 94-101. [CrossRef]

5. Madhuvilakku, R.; Piraman, S. Biodiesel synthesis by $\mathrm{TiO}_{2}-\mathrm{ZnO}$ mixed oxide nanocatalyst catalyzed palm oil transesterification process. Bioresour. Technol. 2013, 150, 55-59. [CrossRef]

6. Wen, Z.; Yu, X.; Tu, S.-T.; Yan, J.; Dahlquist, E. Biodiesel production from waste cooking oil catalyzed by $\mathrm{TiO}_{2}-\mathrm{MgO}$ mixed oxides. Bioresour. Technol. 2010, 101, 9570-9576. [CrossRef]

7. Hernández-Hipólito, P.; García-Castillejos, M.; Martínez-Klimova, E.; Juárez-Flores, N.; Gómez-Cortés, A.; Klimova, T.E. Biodiesel production with nanotubular sodium titanate as a catalyst. Catal. Today 2014, 220-222, 4-11. [CrossRef]

8. Manique, M.C.; Silva, A.P.; Alves, A.K.; Bergmann, C.P. Application of hydrothermally produced $\mathrm{TiO}_{2}$ nanotubes in photocatalytic esterification of oleic acid. Mater. Sci. Eng. B Solid State Mater. Adv. Technol. 2016, 206, 17-21. [CrossRef]

9. Salinas, D.; Guerrero, S.; Araya, P. Transesterification of canola oil on potassium-supported $\mathrm{TiO}_{2}$ catalysts. Catal. Commun. 2010, 11, 773-777. [CrossRef]

10. Salinas, D.; Araya, P.; Guerrero, S. Study of potassium-supported $\mathrm{TiO}_{2}$ catalysts for the production of biodiesel. Appl. Catal. B Environ. 2012, 117-118, 260-267. [CrossRef]

11. Hernández-Hipólito, P.; Juárez-Flores, N.; Martínez-Klimova, E.; Gómez-Cortés, A.; Bokhimi, X.; Escobar-Alarcón, L.; Klimova, T.E. Novel heterogeneous basic catalysts for biodiesel production: Sodium titanate nanotubes doped with potassium. Catal. Today 2015, 250, 187-196. [CrossRef]

12. Martínez-Klimova, E.; Hernández-Hipólito, P.; Klimova, T.E. Biodiesel Production with Nanotubular Sodium Titanate Doped with Potassium as a Catalyst. MRS Adv. 2016, 1, 415-420. [CrossRef]

13. Yahya, N.Y.; Ngadi, N.; Wong, S.; Hassan, O. Transesterification of used cooking oil (UCO) catalyzed by mesoporous calcium titanate: Kinetic and thermodynamic studies. Energy Convers. Manag. 2018, 164, 210-218. [CrossRef]

14. González, E.A.Z.; García-Guaderrama, M.; Villalobos, M.R.; Dellamary, F.L.; Kandhual, S.; Rout, N.P.; Tiznado, H.; Arizaga, G.G.C. Potassium titanate as heterogeneous catalyst for methyl transesterification. Powder Technol. 2015, 280, 201-206. [CrossRef]

15. Salinas, D.; Guerrero, S.; Cross, A.; Araya, P.; Wolf, E.E. Potassium titanate for the production of biodiesel. Fuel 2016, 166, 237-244. [CrossRef]

16. Russbueldt, B.M.E.; Hoelderich, W.F. New rare earth oxide catalysts for the transesterification of triglycerides with methanol resulting in biodiesel and pure glycerol. J. Catal. 2010, 271, 290-304. [CrossRef] 
17. Chew, K.Y.; Tan, W.L.; Bakar, N.H.H.A.; Bakar, M.A. Transesterification of palm cooking oil using barium-containing titanates and their sodium doped derivatives. Int. J. Energy Environ. Eng. 2017, 8, 47-53. [CrossRef]

18. Kasuga, T.; Hiramatsu, M.; Hoson, A.; Sekino, T.; Niihara, K. Formation of Titanium Oxide Nanotube. Langmuir 1998, 14, 3160-3163. [CrossRef]

19. Ji, T.; Tu, R.; Li, L.; Mu, L.; Liu, C.; Lu, X.; Zhu, J. Localizing microwave heat by surface polarization of titanate nanostructures for enhanced catalytic reaction efficiency. Appl. Catal. B Environ. 2018, 227, $266-275$. [CrossRef]

20. Morgado, E.; de Abreu, M.A.S.; Pravia, O.R.C.C.; Marinkovic, B.A.; Jardim, P.M.; Rizzo, F.C.; Araújo, A.S. A study on the structure and thermal stability of titanate nanotubes as a function of sodium content. Solid State Sci. 2006, 8, 888-900. [CrossRef]

21. Ou, H.H.; Lo, S.L. Review of titania nanotubes synthesized via the hydrothermal treatment: Fabrication, modification, and application. Sep. Purif. Technol. 2007, 58, 179-191. [CrossRef]

22. Salinas, D.A.; Marchena, C.L.; Pierella, L.B.; Pecchi, G. Catalytic oxidation of 2-(methylthio)-benzothiazole on alkaline earth titanates, $\mathrm{ATiO}_{3}(\mathrm{~A}=\mathrm{Ca}, \mathrm{Sr}, \mathrm{Ba})$. Mol. Catal. 2017, 438, 76-85. [CrossRef]

23. Morgado, E.; de Abreu, M.A.S.; Moure, G.T.; Marinkovic, B.A.; Jardim, P.M.; Araujo, A.S. Effects of thermal treatment of nanostructured trititanates on their crystallographic and textural properties. Mater. Res. Bull. 2007, 42, 1748-1760. [CrossRef]

24. Qamar, M.; Yoon, C.R.; Oh, H.J.; Kim, D.H.; Jho, J.H.; Lee, K.S.; Lee, W.J.; Lee, H.G.; Kim, S.J. Effect of post treatments on the structure and thermal stability of titanate nanotubes. Nanotechnology 2006, 17, 5922-5929. [CrossRef]

25. Sun, X.; Li, Y. Synthesis and characterization of ion-exchangeable titanate nanotubes. Chem. Eur. J. 2003, 9, 2229-2238. [CrossRef] [PubMed]

26. Aramendía, M.A.; Borau, V.; Jiménez, C.; Marinas, A.; Marinas, J.M.; Ruiz, J.R.; Urbano, F.J. Magnesium-containing mixed oxides as basic catalysts: Base characterization by carbon dioxide TPD-MS and test reactions. J. Mol. Catal. A Chem. 2004, 218, 81-90. [CrossRef]

27. Senguttuvan, P.; Rousse, G.; Seznec, V.; Tarascon, J.M.; Palacín, M.R. $\mathrm{Na}_{2} \mathrm{Ti}_{3} \mathrm{O}_{7}$ : Lowest voltage ever reported oxide insertion electrode for sodium ion batteries. Chem. Mater. 2011, 23, 4109-4111. [CrossRef]

28. An, Y.; Li, Z.; Xiang, H.; Huang, Y.; Shen, J. First-principle calculations for electronic structure and bonding properties in layered $\mathrm{Na}_{2} \mathrm{Ti}_{3} \mathrm{O}_{7}$. Cent. Eur. J. Phys. 2011, 9, 1488-1492. [CrossRef]

29. Cech, O.; Castkova, K.; Chladil, L.; Dohnal, P.; Cudek, P.; Libich, J.; Vanysek, P. Synthesis and characterization of $\mathrm{Na}_{2} \mathrm{Ti}_{6} \mathrm{O}_{13}$ and $\mathrm{Na}_{2} \mathrm{Ti}_{6} \mathrm{O}_{13} / \mathrm{Na}_{2} \mathrm{Ti}_{3} \mathrm{O}_{7}$ sodium titanates with nanorod-like structure as negative electrode materials for sodium-ion batteries. J. Energy Storage 2017, 14, 391-398. [CrossRef]

30. Theobald, F.R.; Catlow, C.R.A.; Cormack, A.N. Lattice energy minimization as a complementary technique to refine structures obtained by high-resolution electron microscopy. J. Solid State Chem. 1984, 52, 80-90. [CrossRef]

31. Bhat, S.S.M.; Babu, B.; Feygenson, M.; Neuefeind, J.C.; Shaijumon, M.M. Nanostructured $\mathrm{Na}_{2} \mathrm{Ti}_{9} \mathrm{O}_{19}$ for Hybrid Sodium-Ion Capacitors with Excellent Rate Capability. ACS Appl. Mater. Interfaces. 2018, 10, 437-447. [CrossRef]

32. Wang, Y.; Liu, H.; Zhang, H.; Yao, X.; Zhao, H. Origin of reactivity diversity of lattice oxygen in titanates. Chem. Phys. Lett. 2011, 511, 82-86. [CrossRef]

33. Wang, Y.; Sun, T.; Yang, D.; Liu, H.; Zhang, H.; Yao, X.; Zhao, H. Structure, reactivity, photoactivity and stability of Ti-O based materials: A theoretical comparison. Phys. Chem. Chem. Phys. 2012, 14, 2333-2338. [CrossRef]

34. X-ray Photoelectron Spectroscopy (XPS) Reference Pages: Titanium, (n.d.). Available online: http://www. xpsfitting.com/2008/09/titanium.html (accessed on 26 July 2019).

35. Roberts, M.W.; Tomellini, M. Mixed oxidation states of titanium at the metal-oxide interface. Catal. Today 1992, 12, 443-452. [CrossRef]

36. Pacchioni, G. Oxygen Vacancy: The Invisible Agent on Oxide Surfaces. Chem. Phys. Chem. 2003, 4, $1041-1047$. [CrossRef] [PubMed]

37. Kim, K.T.; Ali, G.; Chung, K.Y.; Yoon, C.S.; Yashiro, H.; Sun, Y.K.; Lu, J.; Amine, K.; Myung, S.T. Anatase titania nanorods as an intercalation anode material for rechargeable sodium batteries. Nano Lett. 2014, 14, 416-422. [CrossRef] 
38. Wu, L.; Bresser, D.; Buchholz, D.; Giffin, G.A.; Castro, C.R.; Ochel, A.; Passerini, S. Unfolding the Mechanism of Sodium Insertion in Anatase $\mathrm{TiO}_{2}$ Nanoparticles. Adv. Energy Mater. 2015, 5, 1401142. [CrossRef]

39. Liu, H.; Yang, D.; Zheng, Z.; Ke, X.; Waclawik, E.; Zhu, H.; Frost, R.L. A Raman spectroscopic and TEM study on the structural evolution of $\mathrm{Na}_{2} \mathrm{Ti}_{3} \mathrm{O}_{7}$ during the transition to $\mathrm{Na}_{2} \mathrm{Ti}_{6} \mathrm{O}_{13}$. J. Raman Spectrosc. 2010, 41, 1331-1337. [CrossRef]

40. Turki, A.; Kochkar, H.; Guillard, C.; Berhault, G.; Ghorbel, A. Effect of Na content and thermal treatment of titanate nanotubes on the photocatalytic degradation of formic acid. Appl. Catal. B Environ. 2013, 138-139, 401-415. [CrossRef]

41. XPS Interpretation of Titanium, (n.d.). Available online: https://xpssimplified.com/elements/titanium.php (accessed on 26 July 2019).

42. Montgomery, D.C. Design-and-Analysis-of-Experiments, 5th ed.; John Wiley \& Sons, Ltd.: New York, NY, USA, 2001; p. 679.

43. ASTM D6584-17 Standard Test Method for Determination of Total Monoglycerides, Total Diglycerides, Total Triglycerides, and Free and Total Glycerin in B-100 Biodiesel Methyl Esters by Gas Chromatography, (n.d.). Available online: https://www.astm.org/Standards/D6584.htm (accessed on 4 March 2019).

44. EN 14103-European Standards, (n.d.). Available online: https://www.en-standard.eu/csn-en-14103-fat-andoil-derivatives-fatty-acid-methyl-esters-fame-determination-of-ester-and-linolenic-acid-methyl-estercontents/ (accessed on 4 March 2019).

(C) 2019 by the authors. Licensee MDPI, Basel, Switzerland. This article is an open access article distributed under the terms and conditions of the Creative Commons Attribution (CC BY) license (http://creativecommons.org/licenses/by/4.0/). 